\title{
Determinants of Dividend Policy in the Select Indian Manufacturing Industries - An Empirical Investigation
}

\author{
S. Kalaiselvi' and C. Brundha ${ }^{2 *}$ \\ ${ }^{1}$ Associate Professor and Head, Department of Commerce with Computer Applications \\ ${ }^{2}$ Assistant Professor, Department of Commerce, Vellalar College for Women (Autonomous), Erode, Tamil Nadu, India; \\ cbrundha@rediffmail.com
}

\begin{abstract}
Manufacturing sector has been recognized as the main engine for economic growth and creation of wealth in India. Accordingly, emphasis was placed on growth of industry in most of the five year plans formulated by planning commission of India. In the present complex corporate environment, the finance managers need to revise their strategies to manage the challenges posing them. Dividend declaration is considered to be one of the most important criteria for the distribution of value to the shareholders. Dividend policy adopted by a firm has an inference in the practical life for both the managers and the organization's stakeholders. The present study aims to identify the factors determining the dividend policy of select Indian manufacturing companies for a period of 10 financial years from 2005-2006 to 2014-2015. The factors affecting dividend policy of select manufacturing industries in India are identified by using Lintner's Model, Brittain's Cash Flow Model and Brittain's Explicit Depreciation Model. The factors identified with the models and other factors are grouped to extract the major determinants of dividend policy.
\end{abstract}

Keywords: Cash Flow, Depreciation, Dividend Policy, Lagged Dividend, Profit After Tax

\section{Introduction}

Industries are the backbone of any growing economy. Among various industries, manufacturing sector is a key to the growth of Indian economy. The effect of improvement in manufacturing sector goes beyond the goods provided by it. Manufacturing sector sells goods to other sectors and in turn buy materials and services for its growth and development. Among the various manufacturing industries, automobile, textile, chemicals, paper, sugar, construction materials and diversified industries occupy a dominant place in the industrial structure, and are also large and traditional industries in India. The entry of foreign players subject to certain conditions to operate in Indian domestic market increases the level of competition in Indian corporate sector and also ensures more choice to investors companies should adopt

In order to reap the competitive advantage, companies should adopt a defensive dividend policy allowing the retention of more money to meet their pressing contingencies. At the same time an aggressive policy in the dividend payment garners the investors enjoying a wider choice in the liberalized era. Therefore, a dividend policy rests upon the position of thefirm, economic environment, type of industry, shareholders' expectations, and other factors namely capital gains, capital increase and tax.

${ }^{*}$ Author for correspondence 


\section{Review of Literature}

Sudhahar (2010) ${ }^{1}$ identified that the current year profit after tax and dividend paid in the past to be the basic determinants of the dividend policy of Indian Companies. Shaveta Gupta et al. $(2011)^{2}$ investigated the extent of usage of Lintner's model to explain Indian companies' dividend payments. Acharya and Mahapatra $(2012)^{3}$ examined the validity of the Lintner's dividend behaviour model in three major commercial banks of India namely HDFC Bank, ICICI Bank and State Bank of India. Deepa and Mohan Raj (2012) ${ }^{4}$ analysed the dividend policy to identify the factors determining the dividend decision of the select cement companies. Sumninder Kaur Bawa and Prabhjot Kaur (2012) $)^{5}$ studied the dividend policy of Micro, Small and Medium Enterprises (MSMEs) in the Indian manufacturing sector. Chaudhary et al. $(2013)^{6}$ reexamined the applicability of Lintner's (1956) dividend policy in the pharmaceutical sector of India. Sobha Rani and Partha Sarathi $(2013)^{7}$ focused on the determinants of dividend and its performance of select pharmaceutical companies in India.

\section{Objectives of the Study}

- To evaluate the applicability of Lintner's model and extended version of Lintner's model in explaining the dividend policy of Indian manufacturing industries.

- To identify the factors determining the dividend policy of select companies.

\section{Methodology}

The secondary data gathered from CMIE was employed for the study. Further data were collected from various journals, periodicals, research publications, newspapers and related websites.

\subsection{Sample Design}

The selection of sample companies belonging to Manufacturing Sectors in India namely Automobile, Cement, Diversified, Drugs and Pharmaceuticals, Electricity, Fertilizer, Paper, Steel, Sugar and Textile industry was based on the following criteria:

- Indian manufacturing companies, listed either in Bombay Stock Exchange or National Stock Exchange.

- Paid dividend during most of the years of study period and continuous availability of required data for the entire study period.

Accordingly, 5 companies under each of the above stated Indian manufacturing industries were chosen out of many companies satisfying the criteria based on conve- nience sampling method. Finally, 50 companies constituted the total sample set for the study.

\subsection{Period of the Study}

In order to identify the determinants of dividend policy in the select manufacturing industries in India, the study covers a period of 10 financial years from 2005-2006 to 2014-2015.

\section{Lintner's Model}

Lintner's Model (1956) ${ }^{\frac{8}{}}$ is a basic model that incorporates the dominant determinants of corporate dividend decision. The Model states that the historical rate of dividend is generally considered for the determination of current dividend by many companies. In addition, current earnings are invariably the starting point in considering the change in dividend policy. Thus, dividend payout is a function of current year profit after tax and dividend paid in the previous year (lagged dividend), which algebraically expressed as:

$\mathrm{D}_{\mathrm{t}}=\mathrm{a}_{0}+\mathrm{a}_{1} \mathrm{P}_{\mathrm{t}}+\mathrm{a}_{2} \mathrm{D}_{\mathrm{t}-1}+\mathrm{U}$

Where,

$\mathrm{D}_{\mathrm{t}}=$ total equity dividend in period ' $\mathrm{t}$ '

$\mathrm{P}_{\mathrm{t}}=$ profit after tax in period ' $\mathrm{t}$ '

$\mathrm{D}_{\mathrm{t}-1}=$ total equity dividend in period ' $\mathrm{t}-1$ '

$\mathrm{U}=$ error term

The regression results using Lintner's Model for the select Indian manufacturing industries are shown in Table 1.

Table 1 delineates that the overall fit of the regression model measured by $\mathrm{R}^{2}$ and $\mathrm{F}$-value is good in all the select Indian manufacturing industries. The co-efficient of multiple determination $\left(\mathrm{R}^{2}\right)$ varies from 0.385 to 0.737 . Thus, about $38.5 \%$ to $73.7 \%$ of variation in the current year dividend is explained by the variables in Lintner's dividend equation. The F ratio is statistically significant at $1 \%$ level in automobile, diversified, drugs and pharmaceutical, electricity, fertilizer, paper, sugar and textile industries. Similarly, the F ratio is statistically significant at 5\% level in cement and steel industries.

The exogenous variable 'current year profit after tax' has a significant relationship with dividend payment in cement, diversified and fertilizer industry, whereas it has an insignificant relationship with other select industries. Further, the exogenous variable 'lagged dividend' has a significant relationship with dividend payment in all the select industries except cement and diversified industries. It further reveals that lagged dividend is considered as more important and influential for determining the divi- 
Table 1. Regression Results of Lintner's Model

\begin{tabular}{|c|c|c|c|c|c|c|c|}
\hline Name of the Sector & Constant & Profit After Tax & $\begin{array}{c}\text { Lagged } \\
\text { Dividend }\end{array}$ & $\mathbf{R}^{2}$ & $\begin{array}{c}\text { Adjusted } \\
\mathbf{R}^{2}\end{array}$ & F-Value & $\begin{array}{c}\text { DW } \\
\text { Statistics }\end{array}$ \\
\hline Automobile & $\begin{array}{c}165.836 \\
(.745)\end{array}$ & $\begin{array}{l}-.010 \\
(.151)\end{array}$ & $\begin{array}{c}.904^{*} \\
(4.101)\end{array}$ & 0.607 & 0.541 & $9.256^{\star}$ & 2.114 \\
\hline Cement & $\begin{array}{c}-129.305^{\star *} \\
(2.219)\end{array}$ & $\begin{array}{c}38.269^{\star *} \\
(2.586)\end{array}$ & $\begin{array}{l}-.017 \\
(.774)\end{array}$ & 0.452 & 0.361 & $4.953^{\star \star}$ & 1.294 \\
\hline Diversified & $\begin{array}{c}189.120 \\
(1.280)\end{array}$ & $\begin{array}{c}0.830^{\star} \\
(3.462)\end{array}$ & $\begin{array}{l}0.054 \\
(.698)\end{array}$ & 0.635 & 0.579 & $11.305^{\star}$ & 1.986 \\
\hline Drugs & $\begin{array}{l}29.679 \\
(.198)\end{array}$ & $\begin{array}{l}-5.286 \\
(.246)\end{array}$ & $\begin{array}{c}.369^{*} \\
(3.227)\end{array}$ & 0.563 & 0.490 & $7.725^{\star}$ & 2.411 \\
\hline Electricity & $\begin{array}{l}12.844 \\
(.369)\end{array}$ & $\begin{array}{c}-15.654 \\
(1.550)\end{array}$ & $\begin{array}{c}.852^{\star} \\
(3.930)\end{array}$ & 0.737 & 0.693 & $16.817^{\star}$ & 1.943 \\
\hline Fertilizer & $\begin{array}{c}-411.489^{\star} \\
(3.582)\end{array}$ & $\begin{array}{c}44.905^{\star *} \\
(2.313)\end{array}$ & $\begin{array}{c}.678^{\star} \\
(3.277)\end{array}$ & 0.681 & 0.627 & $12.783^{\star}$ & 2.451 \\
\hline Paper & $\begin{array}{l}6.653^{\star *} \\
(1.930)\end{array}$ & $\begin{array}{c}-.894 \\
(1.639)\end{array}$ & $\begin{array}{c}.678^{\star} \\
(4.723)\end{array}$ & 0.701 & 0.651 & $14.078^{\star}$ & 1.623 \\
\hline Steel & $\begin{array}{c}65.002 \\
(.192)\end{array}$ & $\begin{array}{l}-5.730 \\
(.089)\end{array}$ & $\begin{array}{l}.082^{\star *} \\
(2.739)\end{array}$ & 0.385 & 0.283 & $4.561^{\star *}$ & 1.834 \\
\hline Sugar & $\begin{array}{c}107.288 \\
(.878) \\
\end{array}$ & $\begin{array}{l}-27.049 \\
(1.218) \\
\end{array}$ & $\begin{array}{c}.485^{\star} \\
(3.526) \\
\end{array}$ & 0.706 & 0.657 & $14.402^{\star}$ & 2.189 \\
\hline Textile & $\begin{array}{l}2.854 \\
(.257)\end{array}$ & $\begin{array}{c}.059 \\
(1.045)\end{array}$ & $\begin{array}{l}.625^{\star *} \\
(2.390)\end{array}$ & 0.675 & 0.625 & $13.487^{\star}$ & 1.533 \\
\hline
\end{tabular}

Source: Computed from secondary data

* Significant at $1 \%$ level,

** Significant at $5 \%$ level

Figures in brackets denote ' $\mathrm{t}$ ' values of the co-efficient.

dend of the companies during the study period followed by current year profit after tax.

It is inferred from the above analysis that the specification of Lintner's dividend model offers satisfactory explanation of dividend behaviour of the select manufacturing industries in India.

\section{Brittain's Cash Flow Model}

John Brittain (1966) ${ }^{9}$ suggests that 'cash flow' (current year profit after tax plus depreciation) is a better measure of a company's ability to pay dividends, which algebraically is expressed as:

$\mathrm{D}_{\mathrm{t}}=\mathrm{a}+\mathrm{b}_{1} \mathrm{C}_{\mathrm{t}}+\mathrm{b}_{2} \mathrm{D}_{\mathrm{t}-\mathrm{1}}+\mathrm{U}$ (Brittain's First Model)

Where, $\mathrm{D}_{\mathrm{t}}=$ total equity dividend in period' $\mathrm{t}$ '

$\mathrm{C}_{\mathrm{t}}=$ cash flow in period ' $\mathrm{t}$ '

$\mathrm{D}_{\mathrm{t}-1}=$ total equity dividend in period't $\mathrm{t} \mathrm{1}^{\prime}$

$\mathrm{U}=$ error term

The Brittain's Cash Flow regression model considers two variables namely Cash Flow and Lagged Dividend as independent variables and Dividend Payout Ratio as the dependent variable.
The regression results using Brittain's Cash Flow Model for the select Indian manufacturing industries are shown in Table 2.

Table 2 reveals that the overall fit of the regression model measured by $\mathrm{R}^{2}$ and F-value is good in all the select Indian manufacturing industries. The co-efficient of multiple determination $\left(\mathrm{R}^{2}\right)$ varies from 0.432 to 0.695 . Thus, about $43.2 \%$ to $69.5 \%$ of variation in the current year dividend is explained by the variables in Brittain's Cash Flow dividend model. The F ratio is statistically significant at $1 \%$ level in automobile, cement, diversified, drugs and pharmaceutical, electricity, fertilizer, paper, sugar and textile industries. Similarly, the $\mathrm{F}$ ratio is statistically significant at $5 \%$ level in steel industry.

The estimated co-efficient of explanatory variable 'cash flow' is significant at $1 \%$ and at $5 \%$ level in cement and textile industries respectively whereas, it has no significant relationship with dividend payment in all other select industries. Further, the estimated co-efficient of explanatory variable 'lagged dividend' is significant with dividend payment at $1 \%$ level in automobile, cement, diversified, 
Table 2. Regression Results of Brittain's Cash Flow Model

\begin{tabular}{|c|c|c|c|c|c|c|c|}
\hline $\begin{array}{l}\text { Name of the } \\
\text { Sector }\end{array}$ & Constant & Cash Flow & $\begin{array}{l}\text { Lagged } \\
\text { Dividend }\end{array}$ & $\mathbf{R}^{2}$ & $\begin{array}{l}\text { Adjusted } \\
\mathbf{R}^{2}\end{array}$ & F-Value & $\begin{array}{l}\text { DW } \\
\text { Statistics }\end{array}$ \\
\hline Automobile & $\begin{array}{l}-3.677 \\
(.016)\end{array}$ & $\begin{array}{l}.036 \\
(.757)\end{array}$ & $\begin{array}{l}.887^{\star} \\
(4.213)\end{array}$ & 0.624 & 0.561 & $9.954^{*}$ & 2.417 \\
\hline Cement & $\begin{array}{l}59.921^{*} \\
(3.998)\end{array}$ & $\begin{array}{l}-.148^{\star} \\
(3.954)\end{array}$ & $\begin{array}{l}.064^{\star} \\
(4.217)\end{array}$ & 0.630 & 0.568 & $10.195^{\star}$ & 1.549 \\
\hline Diversified & $\begin{array}{l}119.277 \\
(.659)\end{array}$ & $\begin{array}{l}.004 \\
(.054)\end{array}$ & $\begin{array}{l}.929^{*} \\
(4.488)\end{array}$ & 0.621 & 0.563 & $10.66^{*}$ & 1.137 \\
\hline Drugs & $\begin{array}{l}1.316 \\
(.042) \\
\end{array}$ & $\begin{array}{l}.215 \\
(1.735)\end{array}$ & $\begin{array}{l}.217 \\
(1.667) \\
\end{array}$ & 0.649 & 0.590 & $11.080^{*}$ & 2.395 \\
\hline Electricity & $\begin{array}{l}-43.330^{* *} \\
(2.310)\end{array}$ & $\begin{array}{l}.116 \\
(.630) \\
\end{array}$ & $\begin{array}{l}.529^{\star} \\
(4.670) \\
\end{array}$ & 0.695 & 0.644 & $13.640^{*}$ & 1.813 \\
\hline Fertilizer & $\begin{array}{l}-386.634^{\star *} \\
(2.539)\end{array}$ & $\begin{array}{l}.228 \\
(1.148)\end{array}$ & $\begin{array}{l}.861^{\star} \\
(3.941)\end{array}$ & 0.584 & 0.514 & $8.417^{\star}$ & 2.258 \\
\hline Paper & $\begin{array}{l}1.872 \\
(1.868) \\
\end{array}$ & $\begin{array}{l}-.013 \\
(.970)\end{array}$ & $\begin{array}{l}.022^{\star} \\
(3.380)\end{array}$ & 0.661 & 0.604 & $11.693^{\star}$ & 1.146 \\
\hline Steel & $\begin{array}{l}24.045 \\
(.327) \\
\end{array}$ & $\begin{array}{l}-.114 \\
(.994) \\
\end{array}$ & $\begin{array}{l}.205 \\
(1.614)\end{array}$ & 0.432 & 0.337 & $4.558^{\star \star}$ & 1.913 \\
\hline Sugar & $\begin{array}{l}-39.708 \\
(1.893) \\
\end{array}$ & $\begin{array}{l}.034 \\
(.268) \\
\end{array}$ & $\begin{array}{l}.546^{* *} \\
(2.986) \\
\end{array}$ & 0.671 & 0.617 & $12.265^{\star}$ & 2.331 \\
\hline Textile & $\begin{array}{l}-3.918 \\
(-.297)\end{array}$ & $\begin{array}{l}.583^{\star *} \\
(2.589)\end{array}$ & $.059(1.384)$ & 0.693 & 0.645 & $14.655^{\star}$ & 1.546 \\
\hline
\end{tabular}

Source: Computed from secondary data

* Significant at $1 \%$ level, ${ }^{* *}$ Significant at $5 \%$ level

Figures in brackets denote ' $\mathrm{t}$ ' values of the co-efficient.

electricity, fertilizer and paper industries. Similarly, it has a significant relationship with dividend payment at 5\% level in sugar industry.

Hence, it is concluded that the 'lagged dividend' is the major factor influencing the dividend policy decision of the companies under select Indian manufacturing industries during the study period.

\section{Brittain's Explicit Depreciation Model}

Brittain's Explicit Depreciation Model ${ }^{10}$ uses depreciation $\left(A_{t}\right)$ as separate explanatory variable along with current year profit after tax and lagged dividend. Thus, the regression equation is of the form -

$D_{t}=a+b_{1} P_{t}+b_{2} D_{t-1}+b_{3} A_{t}+U$ (Britain's Second Model)

Where, $\mathrm{D}_{\mathrm{t}}=$ total equity dividend in period' $\mathrm{t}$ '

$\mathrm{P}_{\mathrm{t}}=$ profit after tax in period' $\mathrm{t}$ '

$\mathrm{D}_{\mathrm{t}-1}=$ total equity dividend in period' $\mathrm{t}-\mathrm{1}^{\prime}$

$\mathrm{A}_{\mathrm{t}}=$ depreciation charged in period' $\mathrm{t}$ '

$\mathrm{U}=$ error term
The Brittain's Explicit Depreciation model considers three variables namely current year profit after tax, lagged dividend and current year depreciation as independent variables and dividend payout ratio as the dependent variable.

The regression results using Brittain's Explicit Depreciation model for the select Indian manufacturing industries are shown in Table 3.

Table 3 elucidates that the overall fit of the regression model measured by $\mathrm{R}^{2}$ and F-value is good in all the select Indian manufacturing industries except steel industry. The co-efficient of multiple determination $\left(\mathrm{R}^{2}\right)$ varies from 0.402 to 0.886 . Thus, about $40.2 \%$ to $88.6 \%$ of variation in current year dividend is explained by the variables in Brittain's Explicit Depreciation dividend model. The F ratio is statistically significant at $1 \%$ level in automobile, diversified, electricity, fertilizer, paper, sugar and textile industries. Similarly, the F ratio is statistically significant at 5\% level in cement and drugs and pharmaceutical industries.

The estimated co-efficient of explanatory variable 'current year profit after tax' is significant at 5\% level in automobile and cement industries, and it has no significant relationship with dividend payment in all other select industries. Further, the estimated co-efficient of explana- 
Table 3. Regression Results of Brittain's Explicit Depreciation Model

\begin{tabular}{|c|c|c|c|c|c|c|c|c|}
\hline $\begin{array}{l}\text { Name of the } \\
\text { Sector }\end{array}$ & Constant & $\begin{array}{c}\text { Profit After } \\
\text { Tax }\end{array}$ & $\begin{array}{c}\text { Lagged } \\
\text { Dividend }\end{array}$ & $\begin{array}{l}\text { Depre } \\
\text { ciation }\end{array}$ & $\mathbf{R}^{2}$ & Adjusted $R^{2}$ & F-Value & $\begin{array}{c}\text { DW } \\
\text { Statistics }\end{array}$ \\
\hline Automobile & $\begin{array}{c}-24.903 \\
(.160)\end{array}$ & $\begin{array}{l}-.098^{\star *} \\
(2.063)\end{array}$ & $\begin{array}{c}.171 \\
(.727) \\
\end{array}$ & $\begin{array}{c}.391^{\star} \\
(3.997)\end{array}$ & 0.840 & 0.796 & $19.195^{\star}$ & 2.049 \\
\hline Cement & $\begin{array}{c}-133.871^{\star *} \\
(2.321)\end{array}$ & $\begin{array}{c}37.850^{\star *} \\
(2.589)\end{array}$ & $\begin{array}{c}-.090 \\
(1.330)\end{array}$ & $\begin{array}{c}.004 \\
(1.141)\end{array}$ & 0.510 & 0.377 & $3.820^{\star *}$ & 1.523 \\
\hline Diversified & $\begin{array}{c}-156.344 \\
(.910)\end{array}$ & $\begin{array}{c}.046 \\
(.728)\end{array}$ & $\begin{array}{c}.259 \\
(.922)\end{array}$ & $\begin{array}{l}.540^{\star *} \\
(2.802)\end{array}$ & 0.779 & 0.724 & $14.123^{\star}$ & 2.135 \\
\hline Drugs & $\begin{array}{c}-161.614 \\
(.694)\end{array}$ & $\begin{array}{l}14.282 \\
(.508)\end{array}$ & $\begin{array}{l}-.562 \\
(.641)\end{array}$ & $\begin{array}{c}.039 \\
(1.070)\end{array}$ & 0.604 & 0.496 & $5.595^{\star *}$ & 1.979 \\
\hline Electricity & $\begin{array}{l}9.760 \\
(.234) \\
\end{array}$ & $\begin{array}{c}-15.388 \\
(1.439) \\
\end{array}$ & $\begin{array}{l}.893^{\star *} \\
(2.509)\end{array}$ & $\begin{array}{c}.000 \\
(.149) \\
\end{array}$ & 0.738 & 0.666 & $10.305^{\star}$ & 1.943 \\
\hline Fertilizer & $\begin{array}{c}-247.582 \\
(2.033) \\
\end{array}$ & $\begin{array}{l}28.953 \\
(1.603) \\
\end{array}$ & $\begin{array}{c}.292 \\
(1.192) \\
\end{array}$ & $\begin{array}{l}.006^{* *} \\
(2.296)\end{array}$ & 0.784 & 0.725 & $13.314^{*}$ & 2.213 \\
\hline Paper & $\begin{array}{c}6.791 \\
(1.846) \\
\end{array}$ & $\begin{array}{c}-.892 \\
(-1.568) \\
\end{array}$ & $\begin{array}{c}.018 \\
(1.562) \\
\end{array}$ & $\begin{array}{c}.000 \\
(-.177) \\
\end{array}$ & 0.702 & 0.621 & $8.638^{\star}$ & 1.593 \\
\hline Steel & $\begin{array}{c}116.977 \\
(.323) \\
\end{array}$ & $\begin{array}{r}-15.277 \\
(1.568) \\
\end{array}$ & $\begin{array}{c}-.028 \\
(1.562) \\
\end{array}$ & $\begin{array}{c}.005 \\
(.177) \\
\end{array}$ & 0.402 & 0.239 & 2.464 & 1.972 \\
\hline Sugar & $\begin{array}{c}100.577 \\
(.777)\end{array}$ & $\begin{array}{c}-26.770 \\
(1.158)\end{array}$ & $\begin{array}{l}.379 \\
(.935)\end{array}$ & $\begin{array}{c}.007 \\
(.282)\end{array}$ & 0.708 & 0.628 & $8.891^{\star}$ & 2.133 \\
\hline Textile & $\begin{array}{l}138.343 \\
(1.542) \\
\end{array}$ & $\begin{array}{c}7.068 \\
(1.612) \\
\end{array}$ & $\begin{array}{l}-.818^{\star} \\
(4.626)\end{array}$ & $\begin{array}{c}.026^{\star} \\
(9.080) \\
\end{array}$ & 0.886 & 0.855 & $28.407^{\star}$ & 1.895 \\
\hline
\end{tabular}

Source: Computed from secondary data

* Significant at $1 \%$ level, ${ }^{* *}$ Significant at $5 \%$ level

Figures in brackets denote ' $\mathrm{t}$ ' values of the co-efficient.

tory variable 'lagged dividend' has a significant relationship with dividend payment at $1 \%$ level in textile industry and at $5 \%$ level in electricity industry. It has no significant relationship with dividend payment in all other select industries. Similarly, the estimated co-efficient of explanatory variable 'current year depreciation' has a significant relationship with dividend payment at $1 \%$ level in automobile and textile industries and at 5\% level in diversified and fertilizer industries.

Hence, it is concluded that all the independent variables namely lagged dividend, current year profit after tax and depreciation are cohesively influencing the dividend payment of the select manufacturing industries in India.

\section{Determinants of Dividend Policy: Factor Analysis}

In order to categorize the key determinants of corporate dividend payout ratios for Indian manufacturing industries, the technique of Factor Analysis has been used. In the present study, 18 key variables namely Earnings Per Share, Cash Flow, Return on Equity, Debt-Equity Ratio,
Current Ratio, Quick Ratio, Earnings Retention Ratio, Price to Book Value, Capital Expenditure, Profit After Tax, Price Earnings Ratio, Ln of Total Assets (natural Log of Total Assets), Sales Growth, Interest Coverage Ratio, Lagged PAT (Profit After Tax), Lagged Dividend, Ln of NIFTY (natural Log of NIFTY) and Standard Deviation of EPS have been identified and taken up for analysis based on available literature. Further, Bartlett's test of Sphericity and Kaiser-Meyer-Olkin (KMO) $)^{11,12}$ measure of sampling adequacy are applied to the resultant correlation matrix to test the significance of the relationship among the variables. The details of the findings of KMO and Bartlett's test are given in Table 4 .

Table 4. KMO and Bartlett's Test

\begin{tabular}{|c|c|c|c|}
\hline \multirow[b]{2}{*}{ Industry } & \multirow{2}{*}{$\begin{array}{l}\text { KMO } \\
\text { Value }\end{array}$} & \multicolumn{2}{|c|}{ Bartlett's Test of Sphericity } \\
\hline & & $\begin{array}{c}\text { Approximate } \\
\text { Chi-Square }\end{array}$ & Df \\
\hline Automobile & 0.556 & $755.245^{\star}$ & 153 \\
\hline Cement & 0.631 & $956.332^{*}$ & 153 \\
\hline Diversified & 0.589 & $1001.01^{\star}$ & 153 \\
\hline
\end{tabular}




\begin{tabular}{|l|l|l|l|}
\hline $\begin{array}{l}\text { Drugs and } \\
\text { Pharmaceutical }\end{array}$ & 0.592 & $1207.017^{\star}$ & 153 \\
\hline Electrical & 0.515 & $1033.997^{\star}$ & 153 \\
\hline Fertilizer & 0.591 & $875.095^{\star}$ & 153 \\
\hline Paper & 0.595 & $755.975^{\star}$ & 153 \\
\hline Steel & 0.556 & $863.874^{\star}$ & 153 \\
\hline Sugar & 0.542 & $674.627^{\star}$ & 153 \\
\hline Textile & 0.596 & $696.906^{\star}$ & 153 \\
\hline
\end{tabular}

Source: Computed from secondary data

*Significant at $1 \%$ level

Table 4 exhibits the Bartlett's test results being significant at $1 \%$ level for all the select industries, thereby indicating the correlation between the variables. Further, the KMO test Statistic is more than 0.5 in all the select industries, which validates application of the Factor Analysis.

Through the Principal Component Analysis, factors were extracted with the Eigen value being 1 or above for each component. The model identified the factors for the given data which were the co-efficients used to express a standardized variable in terms of the factors. These factor loadings indicate the weight allotted to each factor.

The Varimax Rotation of the factor matrix enabled the identification of the common factors and the computation of the factor score co-efficient for all variables. Based upon the extracted factor scores, the variables were grouped under new naming by clubbing related factors together for the select Indian manufacturing industries as shown in Table 5.

\section{Key Findings and Suggestions}

The analysis of determinants of dividend policy reveals that disbursing dividend to shareholders by the Indian manufacturing companies is positively influenced by the previous year dividend followed by the current year's profit after tax and current year's depreciation. Hence, the companies need to consider the current year's profit position,

Table 5. Naming of Related Factors Extracted in Select Industries

\begin{tabular}{|c|c|c|c|c|c|}
\hline \multicolumn{3}{|c|}{ AUTOMOBILE INDUSTRY } & \multicolumn{3}{|c|}{ CEMENT INDUSTRY } \\
\hline Variables & $\begin{array}{l}\text { Rotated } \\
\text { Factor } \\
\text { Loading }\end{array}$ & $\begin{array}{l}\text { Clubbed Factors and } \\
\% \text { Total Variance }\end{array}$ & Variables & $\begin{array}{l}\text { Rotated } \\
\text { Factor } \\
\text { Loading }\end{array}$ & $\begin{array}{l}\text { Clubbed Factors and } \\
\text { \% Total Variance }\end{array}$ \\
\hline Earnings Per Share & 0.880 & \multirow{5}{*}{$\begin{array}{l}\text { I(4.921) } \\
\text { Liquidity Position } \\
\text { and Earnings } \\
\text { Variability }\end{array}$} & Debt-Equity Ratio & -0.865 & \multirow{7}{*}{$\begin{array}{l}\text { I }(5.490) \\
\text { Capital Structure } \\
\text { and Long Term } \\
\text { Solvency }\end{array}$} \\
\hline Cash Flow & 0.893 & & Capital Expenditure & -0.435 & \\
\hline Current Ratio & 0.813 & & Profit After Tax & 0.906 & \\
\hline Quick Ratio & 0.810 & & Ln of Total Assets & 0.714 & \\
\hline Std. Deviation of EPS & 0.789 & & Interest Coverage Ratio & 0.741 & \\
\hline Return on Equity & 0.598 & \multirow{6}{*}{$\begin{array}{l}\mathrm{II}(3.887) \\
\text { Stability in Dividend } \\
\text { Payment and Capital } \\
\text { Structure }\end{array}$} & Lagged PAT & 0.954 & \\
\hline Debt-Equity Ratio & -0.481 & & Lagged Dividend & 0.600 & \\
\hline Price to Book Value & 0.661 & & Earnings Per Share & 0.905 & \multirow{3}{*}{$\begin{array}{l}\mathrm{II}(3.447) \\
\text { Financial Soundness } \\
\text { and Earnings } \\
\text { Variability }\end{array}$} \\
\hline Interest Coverage Ratio & 0.633 & & Cash Flow & 0.958 & \\
\hline Lagged PAT & 0.581 & & Std. Deviation of EPS & 0.714 & \\
\hline Lagged Dividend & 0.893 & & Earnings Retention Ratio & -0.499 & \multirow{3}{*}{$\begin{array}{l}\operatorname{III}(2.130) \\
\text { Retained Earnings } \\
\text { and Share Valuation }\end{array}$} \\
\hline Capital Expenditure & 0.877 & \multirow{3}{*}{$\begin{array}{l}\text { III }(1.549) \\
\text { Firm size and } \\
\text { Profitability }\end{array}$} & Price Earnings Ratio & 0.763 & \\
\hline Profit After Tax & 0.733 & & Ln of NIFTY & 0.782 & \\
\hline Ln of Total Assets & 0.833 & & Current Ratio & 0.977 & \multirow{2}{*}{$\begin{array}{l}\text { IV }(2.060) \\
\text { Liquidity Position }\end{array}$} \\
\hline Earnings Retention Ratio & 0.710 & \multirow{2}{*}{$\begin{array}{l}\text { IV }(1.495) \\
\text { Retained Earnings } \\
\text { and Growth Rate }\end{array}$} & Quick Ratio & 0.976 & \\
\hline Sales Growth & 0.846 & & Return on Equity & 0.639 & \multirow{3}{*}{$\begin{array}{l}\mathrm{V}(1.241) \\
\text { Earnings and } \\
\text { Growth Rate }\end{array}$} \\
\hline Ln of NIFTY & 0.932 & $\begin{array}{l}\mathrm{V}(1.343) \\
\text { Share Price } \\
\text { Behaviour }\end{array}$ & Price to Book Value & 0.685 & \\
\hline Price Earnings Ratio & 0.925 & $\begin{array}{l}\text { VI(1.263) } \\
\text { Share Valuation }\end{array}$ & Sales Growth & 0.884 & \\
\hline
\end{tabular}




\begin{tabular}{|c|c|c|c|c|c|}
\hline \multicolumn{3}{|c|}{ DIVERSIFIED INDUSTRY } & \multicolumn{3}{|c|}{ DRUGS AND PHARMACEUTICAL INDUSTRY } \\
\hline Earnings Per Share & 0.958 & \multirow{4}{*}{$\begin{array}{l}\mathrm{I}(5.097) \\
\text { Cash Flow Quality } \\
\text { and Profitability }\end{array}$} & Earnings Per Share & 0.969 & \multirow{6}{*}{$\begin{array}{l}\mathrm{I}(5.634) \\
\text { Financial Soundness } \\
\text { and Earnings } \\
\text { Variability }\end{array}$} \\
\hline Cash Flow & 0.954 & & Cash Flow & 0.975 & \\
\hline Return on Equity & 0.809 & & Return on Equity & 0.764 & \\
\hline Profit After Tax & 0.946 & & Capital Expenditure & 0.668 & \\
\hline Current Ratio & 0.681 & \multirow{5}{*}{$\begin{array}{l}\mathrm{II}(2.779) \\
\text { Stability in Dividend } \\
\text { Payment and } \\
\text { Liquidity Position }\end{array}$} & Profit After Tax & 0.923 & \\
\hline Quick Ratio & 0.690 & & Std. Deviation of EPS & 0.734 & \\
\hline Lagged PAT & 0.817 & & Earnings Retention Ratio & -0.823 & \multirow{3}{*}{$\begin{array}{l}\mathrm{II}(2.824) \\
\text { Profitability and } \\
\text { Retained Earnings }\end{array}$} \\
\hline Lagged Dividend & 0.779 & & Price Earnings Ratio & 0.654 & \\
\hline Std. Deviation of EPS & 0.610 & & Lagged PAT & 0.896 & \\
\hline Earnings Retention Ratio & -0.732 & \multirow{3}{*}{$\begin{array}{l}\mathrm{III}(1.862) \\
\text { Retained Earnings } \\
\text { and Share Price } \\
\text { Behaviour }\end{array}$} & Current Ratio & 0.831 & \multirow{2}{*}{$\begin{array}{l}\text { III }(2.132) \\
\text { Liquidity Position }\end{array}$} \\
\hline Capital Expenditure & 0.592 & & Quick Ratio & 0.822 & \\
\hline Ln of NIFTY & 0.812 & & Price to Book Value & 0.722 & \multirow{4}{*}{$\begin{array}{l}\text { IV }(1.853) \\
\text { Firm Size and Share } \\
\text { Price Behaviour }\end{array}$} \\
\hline Debt-Equity Ratio & 0.861 & \multirow{3}{*}{$\begin{array}{l}\text { IV }(1.824) \\
\text { Firm Size and } \\
\text { Capital Structure }\end{array}$} & Ln of Total Assets & 0.801 & \\
\hline Price to Book Value & 0.514 & & Sales Growth & 0.561 & \\
\hline Ln of Total Assets & 0.835 & & Ln of NIFTY & 0.481 & \\
\hline Price Earnings Ratio & 0.802 & $\begin{array}{l}\mathrm{V}(1.268) \\
\text { Share Valuation }\end{array}$ & Lagged Dividend & 0.972 & $\begin{array}{l}\mathrm{V}(1.206) \\
\text { Stability in Dividend } \\
\text { Payment }\end{array}$ \\
\hline Sales Growth & -0.776 & VI(1.089) & Debt-Equity Ratio & -0.802 & $\mathrm{VI}(1.029)$ \\
\hline Interest Coverage Ratio & 0.511 & $\begin{array}{l}\text { Long term Solvency } \\
\text { and Growth Rate }\end{array}$ & Interest Coverage Ratio & 0.620 & $\begin{array}{l}\text { and Long term } \\
\text { Solvency }\end{array}$ \\
\hline \multicolumn{3}{|c|}{ ELECTRICAL INDUSTRY } & \multicolumn{3}{|c|}{ FERTILIZER INDUSTRY } \\
\hline Earnings Per Share & 0.946 & \multirow{6}{*}{$\begin{array}{l}\mathrm{I}(5.432) \\
\text { Financial Soundness } \\
\text { and Size of the Firm }\end{array}$} & Earnings Per Share & 0.770 & \multirow{5}{*}{$\begin{array}{l}\mathrm{I}(5.218) \\
\text { Profitability and } \\
\text { Cash Flow Quality }\end{array}$} \\
\hline Cash Flow & 0.940 & & Cash Flow & 0.752 & \\
\hline Profit After Tax & 0.775 & & Return on Equity & 0.756 & \\
\hline Ln of Total Assets & 0.842 & & Earnings Retention Ratio & 0.820 & \\
\hline Interest Coverage Ratio & 0.748 & & Profit After Tax & 0.675 & \\
\hline Lagged PAT & 0.845 & & Current Ratio & 0.927 & \multirow{3}{*}{$\begin{array}{l}\mathrm{II}(2.667) \\
\text { Liquidity Position } \\
\text { and Share Valuation }\end{array}$} \\
\hline Debt-Equity Ratio & -0.574 & \multirow{4}{*}{$\begin{array}{l}\mathrm{II}(3.366) \\
\text { Capital Structure } \\
\text { and Liquidity } \\
\text { Position }\end{array}$} & Quick Ratio & 0.945 & \\
\hline Current Ratio & 0.897 & & Price Earnings Ratio & -0.573 & \\
\hline Quick Ratio & 0.900 & & Ln of Total Assets & 0.707 & \multirow{3}{*}{$\begin{array}{l}\operatorname{III}(2.023) \\
\text { Firm Size and } \\
\text { Stability in Dividend } \\
\text { Payment }\end{array}$} \\
\hline Lagged Dividend & -0.457 & & Lagged PAT & 0.856 & \\
\hline Return on Equity & 0.839 & \multirow{3}{*}{$\begin{array}{l}\mathrm{III}(2.082) \\
\text { Dividend Signaling } \\
\text { and Smoothing }\end{array}$} & Lagged Dividend & 0.582 & \\
\hline Price to Book Value & 0.820 & & Capital Expenditure & 0.612 & \multirow{3}{*}{$\begin{array}{l}\text { IV }(1.792) \\
\text { Growth Rate } \\
\text { and Share Price } \\
\text { Behaviour }\end{array}$} \\
\hline Price Earnings Ratio & 0.811 & & Sales Growth & -0.643 & \\
\hline Earnings Retention Ratio & 0.834 & \multirow{3}{*}{$\begin{array}{l}\mathrm{IV}(1.795) \\
\text { Retained Earnings } \\
\text { and Share Price } \\
\text { Behaviour }\end{array}$} & Ln of NIFTY & 0.819 & \\
\hline Sales Growth & 0.604 & & Price to Book Value & 0.595 & \multirow{2}{*}{$\begin{array}{l}\mathrm{V}(1.402) \\
\text { Earnings Variability }\end{array}$} \\
\hline Ln of NIFTY & -0.605 & & Std. Deviation of EPS & -0.679 & \\
\hline Capital Expenditure & -0.779 & \multirow{2}{*}{$\begin{array}{l}\mathrm{V}(1.208) \\
\text { Earnings Variability }\end{array}$} & Debt-Equity Ratio & -0.876 & \multirow{2}{*}{$\begin{array}{l}\text { VI(1.114) } \\
\text { Capital Structure } \\
\text { and Long term } \\
\text { Solvency }\end{array}$} \\
\hline Std. Deviation of EPS & 0.728 & & Interest Coverage Ratio & 0.555 & \\
\hline
\end{tabular}




\begin{tabular}{|c|c|c|c|c|c|}
\hline \multicolumn{3}{|c|}{ PAPER INDUSTRY } & \multicolumn{3}{|c|}{ STEEL INDUSTRY } \\
\hline Earnings Per Share & 0.846 & \multirow{5}{*}{$\begin{array}{l}\mathrm{I}(5.365) \\
\text { Financial Soundness } \\
\text { and Earnings } \\
\text { Variability }\end{array}$} & Profit After Tax & 0.812 & \multirow{4}{*}{$\begin{array}{l}\mathrm{I}(4.895) \\
\text { Profitability and } \\
\text { Long Term Solvency }\end{array}$} \\
\hline Cash Flow & 0.752 & & Ln of Total Assets & 0.746 & \\
\hline Return on Equity & 0.887 & & Interest Coverage Ratio & 0.694 & \\
\hline Price to Book Value & 0.834 & & Lagged PAT & 0.918 & \\
\hline Std. Deviation of EPS & 0.768 & & Earnings Per Share & 0.887 & \multirow{3}{*}{$\begin{array}{l}\mathrm{II}(3.309) \\
\text { Stability in Dividend } \\
\text { Payment and Cash } \\
\text { Flow Quality }\end{array}$} \\
\hline Current Ratio & 0.961 & \multirow{4}{*}{$\begin{array}{l}\mathrm{II}(3.046) \\
\text { Long Term Solvency } \\
\text { and Liquidity } \\
\text { Position }\end{array}$} & Cash Flow & 0.895 & \\
\hline Quick Ratio & 0.940 & & Lagged Dividend & 0.794 & \\
\hline Interest Coverage Ratio & 0.590 & & Return on Equity & 0.812 & \multirow{4}{*}{$\begin{array}{l}\text { III(2.332) } \\
\text { Firms' Growth } \\
\text { and Share Price } \\
\text { Behaviour }\end{array}$} \\
\hline Ln of NIFTY & -0.572 & & Price to Book Value & 0.590 & \\
\hline Debt-Equity Ratio & -0.620 & \multirow{5}{*}{$\begin{array}{l}\mathrm{III}(2.504) \\
\text { Capital Structure } \\
\text { and Profitability }\end{array}$} & Sales Growth & 0.715 & \\
\hline Earnings Retention Ratio & 0.585 & & Ln of NIFTY & -0.601 & \\
\hline Profit After Tax & 0.533 & & Current Ratio & 0.928 & \multirow{3}{*}{$\begin{array}{l}\text { IV(1.628) } \\
\text { Liquidity Position }\end{array}$} \\
\hline Lagged PAT & 0.861 & & Quick Ratio & 0.937 & \\
\hline Lagged Dividend & 0.823 & & Capital Expenditure & -0.650 & \\
\hline Capital Expenditure & -0.657 & \multirow{2}{*}{$\begin{array}{l}\text { IV }(1.384) \\
\text { Size of the Firm }\end{array}$} & Earnings Retention Ratio & 0.773 & \multirow{2}{*}{$\begin{array}{l}\mathrm{V}(1.415) \\
\text { Retained Earnings } \\
\text { and Earnings } \\
\text { Variability }\end{array}$} \\
\hline Ln of Total Assets & 0.709 & & Std. Deviation of EPS & 0.852 & \\
\hline Price Earnings Ratio & -0.710 & \multirow{2}{*}{$\begin{array}{l}\mathrm{V}(1.211) \\
\text { Share Valuation and } \\
\text { Firms' Growth }\end{array}$} & Debt-Equity Ratio & -0.654 & \multirow{2}{*}{$\begin{array}{l}\mathrm{VI}(1.169) \\
\text { Capital Structure } \\
\text { and Share Valuation }\end{array}$} \\
\hline Sales Growth & 0.615 & & Price Earnings Ratio & 0.762 & \\
\hline \multicolumn{3}{|c|}{ SUGAR INDUSTRY } & \multicolumn{3}{|c|}{ TEXTILE INDUSTRY } \\
\hline Earnings Per Share & 0.856 & \multirow{4}{*}{$\begin{array}{l}\mathrm{I}(4.843) \\
\text { Financial Soundness } \\
\text { and Long Term } \\
\text { Solvency }\end{array}$} & Earnings Per Share & 0.835 & \multirow{5}{*}{$\begin{array}{l}\mathrm{I}(4.002) \\
\text { Cash Flow Quality } \\
\text { and Capital } \\
\text { Structure }\end{array}$} \\
\hline Cash Flow & 0.895 & & Cash Flow & 0.879 & \\
\hline Interest Coverage Ratio & 0.533 & & Return on Equity & 0.824 & \\
\hline Std. Deviation of EPS & 0.787 & & Debt-Equity Ratio & 0.538 & \\
\hline Return on Equity & 0.824 & \multirow{3}{*}{$\begin{array}{l}\mathrm{II}(2.919) \\
\text { Profitability and } \\
\text { Growth Rate }\end{array}$} & Std. Deviation of EPS & 0.532 & \\
\hline Profit After Tax & 0.888 & & Profit After Tax & 0.809 & \multirow{3}{*}{$\begin{array}{l}\mathrm{II}(3.263) \\
\text { Profitability and } \\
\text { Stability in Dividend } \\
\text { Payment }\end{array}$} \\
\hline Sales Growth & 0.685 & & Lagged PAT & 0.753 & \\
\hline Price to Book Value & 0.586 & \multirow{3}{*}{$\begin{array}{l}\text { III(1.965) } \\
\text { Stability in Dividend } \\
\text { Payment }\end{array}$} & Lagged Dividend & 0.734 & \\
\hline Lagged PAT & 0.895 & & Current Ratio & 0.959 & $\operatorname{III}(2.088)$ \\
\hline Lagged Dividend & 0.929 & & Quick Ratio & 0.958 & Liquidity Position \\
\hline Current Ratio & 0.840 & \multirow{3}{*}{$\begin{array}{l}\text { IV }(1.583) \\
\text { Firm Size and } \\
\text { Liquidity Position }\end{array}$} & Earnings Retention Ratio & 0.419 & \multirow{4}{*}{$\begin{array}{l}\text { IV }(1.580) \\
\text { Firm Size and Long } \\
\text { Term Solvency }\end{array}$} \\
\hline Quick Ratio & 0.888 & & Capital Expenditure & 0.584 & \\
\hline Ln of Total Assets & -0.444 & & Ln of Total Assets & -0.733 & \\
\hline Debt-Equity Ratio & 0.579 & \multirow{3}{*}{$\begin{array}{l}\mathrm{V}(1.274) \\
\text { Capital Structure } \\
\text { and Retained } \\
\text { Earnings }\end{array}$} & Interest Coverage Ratio & 0.737 & \\
\hline Earnings Retention Ratio & 0.719 & & Price to Book Value & 0.612 & \multirow{2}{*}{$\begin{array}{l}\mathrm{V}(1.332) \\
\text { Share Valuation }\end{array}$} \\
\hline Capital Expenditure & -0.675 & & Price Earnings Ratio & 0.790 & \\
\hline Price Earnings Ratio & 0.871 & \multirow[b]{2}{*}{$\begin{array}{l}\text { VI }(1.160) \\
\text { Share Price } \\
\text { Behaviour }\end{array}$} & Sales Growth & -0.729 & \multirow{2}{*}{$\begin{array}{l}\mathrm{VI}(1.115) \\
\text { Growth rate } \\
\text { and Share Price } \\
\text { Behaviour }\end{array}$} \\
\hline Ln of NIFTY & 0.534 & & Ln of NIFTY & 0.532 & \\
\hline
\end{tabular}

Source: Computed from secondary data 
depreciation and the past dividend policy before taking dividend decision. Further, the quality of cash flows denoting the liquidity of the firm, and the firm size are significant determinants of the dividend payout in most of the select manufacturing industries.

\section{Conclusion}

Manufacturing sector fuels growth, productivity, employment and strengthens agricultural and service sectors. The finance managers of manufacturing industries have to make critical financial decisions to remain competitive in the market. From the analysis it is inferred that Lagged Dividend, Earnings Per Share, Return on Equity and Retained Earnings act as important variables in determining the Dividend Policy of most of the manufacturing industries in India. Hence, the companies under Manufacturing sector have to concentrate more on the formulation of optimal dividend policy which enhances the shareholders' value by giving due weightage for both earnings distribution and firms' growth opportunities.

\section{References}

1. Sudhahar M. Determinants of Dividend Policy in Selected Indian Industries: An Empirical Analysis. Indian Journal of Finance. 2010 December; 4(12):29-39. ISSN 0973-8711.

2. Shaveta Gupta, Balram Dogra and Vashisht AK. A Study on Validity of Lintner's Model of Dividend in Indian Companies. International Journal of Financial Management. 2011 October; 1(4):63-70.

3. Acharya and Mahapatra. Validity of Lintner's Dividend Behaviour Model in Indian Banking Sector: An Empirical Analysis. Management Insight. 2012 June; 8(1):72-6.

4. Deepa and Mohan Raj. Determinants of Corporate Dividend Policy in Select Private Sector Cement Companies in
Tamil Nadu - An Empirical Analysis. International Journal of Research in Commerce and Management. 2012 July; 3(7):107-13. ISSN 0976-2183.

5. Sumninder Kaur Bawa and Prabhjot Kaur. Empirical Validity of Dividend Policy Models in the Indian Manufacturing MSMEs. Excel International Journal of Multidisciplinary Management Studies. 2012 January; 2(2):18-39. ISSN 22498834 .

6. Chaudhary Rashmi CA, Khare Sumi. Examining Application of Lintner's Dividend Model in the Indian Pharmaceutical Industry. Journal of Venture Capital and Financial Services. 2013 January-December; 7(1/2):5-16.

7. Sobha Rani and Partha Sarathi. Determinants of Dividends in Indian Pharmaceutical Companies. International Journal of Scientific and Research Publications. 2013 May; 3(5):1-5. ISSN 2305-8277.

8. Lintner J. Distribution of Incomes of Corporation among Dividends, Retained Earnings and Taxes. The American Economic Review. 1956 May; 46(2):97-113.

9. Brittain JA. Corporate Dividend Policy. Washington, DC: The Brookings Institution. 1966; 7-12.

10. Brittain, JA. Corporate Dividend Policy. Washington, DC: The Brookings Institution. 1966; Chapter IV.

11. Hair J, Anderson RE, Tatham RL, Black WC. Multivariate data analysis, 4th ed. New Jersey: Prentice Hall Inc. 1995: 373.

12. Tabachnick BG, Fidell IS. Using Multivariate Statistics. Boston: Pearson Educational Inc. 2007; 611.

\section{Other References}

13. Chandra Sekhar Mishra and Vunyale Narendar. Dividend Policy of SOEs in India - An Analysis. Finance India. 1996 September; 10(3):633-45.

14. Jasvir S Sura, Karam Pal and Bodla BS. Factors Influencing Dividend Policy Decisions in Banking Sector: An Indian Evidence. Amity Business Review. 2006 June-December; $7(2): 64-75$. 